\title{
Interview with Francisco Vázquez García
}

\begin{abstract}
With more than twenty books and varied articles, Francisco Vázquez García, Spanish philosopher and historian, shares with us about his projects, his passion for Foucault, and introduces us to the method of the sociology of philosophy. He also comments on his intellectual adventure through the history of sexuality in Spain. This is the second part of the interview with Professor Francisco Vázquez García of the University of Cádiz about his visit to Chile in October 2014.
\end{abstract}

Keywords: Vázquez García, history of sexuality in Spain, variable geometry, declining plurality of biopolitics, canguilhem, foucault, ortega, zubiri
Volume 3 Issue 3 - 2018

\section{Daniel Toscano López}

Investigador, Centro de bioética, Facultad de Medicina, Universidad del Desarrollo, Chile

Correspondence: Daniel Toscano López, Investigador, Centro de bioética, Facultad de Medicina, Universidad del Desarrollo, Chile, Tel 56978298 209, Email dtoscano@udd.cl

Received: December 10, 2017 | Published: May 22, 2018

\section{Introduction}

\section{Daniel Toscano}

Tell us a little about your professional and academic training

\section{Francisco Vázquez García}

I studied a degree in philosophy and science of education at the University of Seville, where I presented my "dissertation" in 1984 (what would now be a thesis) on Georges Canguilhem. Later I got a scholarship of research to do the doctoral thesis at the University of Cádiz, about Michel Foucault and contemporary French historiography. The work was directed by Mariano Peñalver (19302005), whom I consider my teacher. He was one of those who introduced structuralism and hermeneutics in Spain. Unlike most of the philosophy professors of his generation, he had trained in France, and not in Germany. He attended the classes of Lévy-Strauss and was one of the greatest specialists in Ricoeur's. I defended the thesis in 1987, doing my doctorate in History at the University of Cádiz. Then (1988-89) I make a stay at the Center Michel Foucault (while still in Saulchoir) and in 1989 I was a provisional Professor of University School, obtaining the position in 1991, at the University of Cádiz. In the 1994-95 academic year, I was a visiting researcher at the Center de Recherches Historiques de EHESS, following the seminars of Jean Louis Flandrin. In 2004 I obtained the Chair of Philosophy at the Faculty of Philosophy and Letters (University of Cádiz). I was dean of this center in 2004-2005. I have been a visiting professor to give lectures in different European and Latin American Universities.

\section{Toscano}

Why he has been interested in working the history of sexuality in Spain

\section{Vázquez}

The history of sexuality is a privileged observatory to explore the history of subjectivities. It is one of the scenarios where what Foucault called "dividing practices" is more exposed: split between the prostitute and the honest woman, the perverse and the sexually healthy individual, the effeminate and the virile, the ambiguous and profiled identities, the dirty and pure individuals, etc. The institution of sexuality is a privileged enclave to follow the social process of "making people", as Ian Hacking ${ }^{1}$ calls it. On the other hand, in Spain, ${ }^{1}$ Hacking I. Making up people. In: Thomas CH, Morton S, David EW, editors. Reconstructing Individualism, Autonomy, Individuality, and the self in Western in the same way as in other countries, sexuality has made many people suffer. Let us think of course of the era of national-Catholicism, during Franco's dictatorship, but also in the early days of the democratic transition, when many readers of Reich and Marcuse considered sexual liberation an obligation. When Andrés and I wrote Sex and Reason, ${ }^{2}$ we had in view the situation of sexuality in the post-transitional period of Spain, during the first socialist governments. Sexuality began to be seen less as a matter of political emancipation and more and more as a question linked to caring for oneself in the new middle classes. The sexological consultations or television programs like Let's talk about sex, aroused enormous interest. At the same time, at the height of AIDS infections (which for many people associated illness and death with sexual deviation), sexuality was still linked to great collective panics, with homosexuality and pedophilia mingling (for example, in the Arny pub scandal, in 1995), aristocracy and perversion (the scandal that led to the arrest of the Duke of Feria, in 1993) or vote of chastity and pedophilia (the first Spanish studies on pedophile priests date from the $90 \mathrm{~s}$ ). This ambivalence of a society that was at the same time tolerant but afraid of sexual diversity attracted our attention and was a decisive stimulus to dedicate ourselves to this field of research. ${ }^{3}$

\section{Toscano}

I like to imagine the craft of philosophy links itself to the image of the jewellery workshop, because it uses the hammer and the crucible to strike and melt, respectively, the materials with which he will achieve new figures. If we could attend his workshop of philosophical and intellectual creation, what would we find? Can you describe us what things do you do with the concepts?

\section{Vázquez}

I try to make them work in relation to very diverse empirical materials, whether brothel regulations, school architectures, tables of dissection, urban designs of colonies, statements of theology, hygiene or criminal anthropology, lives of obscure and unfortunate individuals narrated in clinical cases, criminal processes or journalistic sketches.

Thought. California: Stanford, Stanford University Press; 1986. Hacking I. Making up People. London: Review of books, 2006. p. 23-26.

${ }^{2}$ Vázquez F, Moreno A. Sexo y razón. Una genealogía de la moral sexual en España. siglos XVI-XX. Madrid: editorial Akal. 1997. Vázquez F, Moreno A. Historia de la prostitución en Andalucía. Fund. José Manuel Lara: 2004.

3Vázquez F, Cleminson R. "Los invisibles". A history of Male Homosexuality in Spain (1850-1940), Cardiff: University of Wales Press, Iberian and Latin American Studies, 2007. Traducido al castellano en la editorial Comares, Granada, 2012. 
I believe that the job would be that of mounting block of collages, if we want to use this metaphor. Also it might be a question of the work of "moulder", catching the free pieces, by means of the concepts, in a sort of metallic formwork. The concepts allow to gather these diverse and independent pieces, found here and there.

\section{Toscano}

How do you see yourself, consider yourself a philosopher, historian, sociologist, genealogist, interdisciplinary researcher?

\section{Vázquez}

A professor of philosophy. The philosopher's label is reserved to some few ones. Of course, a professor who teaches philosophy (in class or through writing) using historical materials.

\section{Toscano}

There are two expressions that you coin and that refer to the care and the shades that exist at the moment of investigating the biopolitics: "Variable geometry" and "declining plurality of biopolitics". Could you, please, clarify the context of where they arise and where they point to?

\section{Vázquez}

When I say "variable geometry," I mean the changing character of biopolitics configurations. Foucault points out that the government of life crystallized from the late eighteenth century, combines three types of power technologies: law (sovereignty), disciplines and regulations (or security measures). These form a "triangle", says Foucault, ${ }^{4}$ which transforms in the change of a governmental rationality to other one. Because of it the metaphor of the variable geometry of this triangle. Because of it also the biopolitics is declined in plural, in historical configurations that transform.

\section{Toscano}

Tell us about your intellectual sources, which are the authors that have inspired your work.

\section{Vázquez}

For what has been said, it seems clear: Foucault, Canguilhem, Bourdieu, and the progeny of the Annales: Febvre, Bloch, Braudel, Duby, above all.

\section{Toscano}

What is it that captivates you to study intellectuals like Foucault, Bourdieu or Canguilhem himself? Is it a coincidence that your works are influenced by French or is there something in your styles that you capitalize appropriately on your research?

\section{Vázquez}

I have been trained in this tradition. I suppose that this is influenced by the French profile of my teacher, Mariano Peñalver, and that of another teacher, also Frenchified, who had a decisive influence on my philosophical education, which is called Rosario García del Pozo. I had a great-grandfather, a military man and a freemason, who admired and avidly read Voltaire, I suppose, as we say in my country, that "de casta le viene al galgo".

${ }^{4}$ Foucault M. Seguridad, territorio, población. Trad. Horacio Pons. Buenos Aires: Fondo de Cultura Económica, 2006. p. 10.

\section{Toscano}

Two giants of philosophy in Spain are undoubtedly Ortega and Zubiri. With which of the two is more identified. Tell us why.

\section{Vázquez}

Without a doubt with Ortega y Gasset. I have read it more and I recognize myself closer to his philosophical style. It is true that Zubiri gives great importance to dialogue with the sciences, such as Ortega. But in the case of Zubiri, the science of reference and discussion is above all physics, in which I lack preparation. However, the hybrid philosophy of Ortega takes as reference the Humanities, especially History, and partly biology, territories that are closer to me. On the other hand, I prefer the essay, its agility and its diagnostic reference to the present, against the timeless and systematic language of Sobre la esencia e Inteligencia Sentiente. All this, of course, without denying the greatness of Zubiri. Together with Ortega, Gaos, García Morente and María Zambrano, the school of Madrid is the best crop of Spanish philosophy, from the time of Suárez and the school of Salamanca.

\section{Toscano}

We know about the avatars that philosophy goes through in Spain with the LOMCE law (Organic Law for the improvement of educational quality). You can tell us what the spirit of the law claims. What effects, of course disastrous, do you consider may arise? How to resist that strategy of power over the heart of thinking itself that is philosophy?

\section{Vázquez}

The worst thing is that this reduction in philosophy hours does not respond to a planned strategy. It has been cut by itself, to leave more room for teachings that are considered "more social demand" or ideologically more exploitable (as with the History of Spain at this time). I think that the existence of philosophy classes are like social security contributions: a historical conquest. Well faced, the philosophy class must teach "standing thinking" (the expression is Canguilhem's), that is, to assert the universal demands of reason, of justice, of equality, against all submission to particular interests of the nation, race or company. Philosophy is the teaching of the intellectual DNA of democracy, it is consubstantial with the formation of critical provisions that allow citizens to be made in a democracy. Cutting it out is making things easier for those who want to promote the particular interests mentioned above. But as I say, the worst thing is that the cut, like others that we suffer in Spain, does not even follow a concerted plan. To resist you have to associate, mobilize and become visible. There are comrades who are doing an extraordinary and admirable endeavor in this. We all have to collaborate like them. I would like, at least, to mention one of these colleagues: Antonio Campillo, dean of the faculty of philosophy of Murcia and president of the Spanish Societies of Philosophy.

\section{Toscano}

To conclude this interview, tell us about your editorial projects, what topics and problems are you investigating now?

\section{Vázquez}

In November, a book called Hijos de Dionisos. Sociogénesis de una vanguardia filosófica (1968-1985). It is an analysis, made from the perspective of the sociology of philosophy, of the formation of 
the group of "neonietzscheanos" that had a great role in the Spanish philosophical universe of the period indicated. The names that most sound of this group are those of Fernando Savater, Eugenio Trías and Rubert de Ventós. It is an intellectual bohemian that imported the French readings of Nietzsche made by authors such as Deleuze, Klossowski, Foucault or Bataille. He shaped a sort of Nietzschean left, an alternative both to the old Thomism of official philosophy and to the alternative alternatives that represented Marxism and analytical philosophy. On the other hand, in the sabbatical year that I enjoy now I am going to develop a project that revolves around Canguilhem's philosophy. This author, for scarcely a decade and following the rediscovery of an important corpus of texts of his youth, is receiving an increasing interest in the whole philosophical planet. He was tended to consider himself as a secondary author, disciple of Bachelard and teacher of Foucault, Bourdieu or Althusser. Today he is considered a philosopher of the first order and with his own right. Faced with the received doctrine, he is not recognized only as a historian of the sciences and epistemologist, but mainly as a philosopher of ethicalpolitical vocation.

Finally, my project, on the one hand, tries to examine some connections between Canguilhem and Spanish culture (comparison with Ortega's ratiovitalism, with Laín's medical anthropology, repercussion of the Civil War on his intellectual and political trajectory). On the other hand, I would like to use Canguilhem's "toolbox", especially his analysis of the relationship between vital normativity and social normativity, to examine certain epistemological and political debates concerning the movement of the disabled, within what in the Anglophone world are called "Disability Studies". Ultimately, I would like to carry out a sociogenetic study of Canguilhem's philosophy, such as those we have done on other authors in our research team at the University of Cádiz.

\section{Acknowledgements}

None.

\section{Conflict of interest}

Author declares there is no conflict of interest.

\section{References}

1. Hacking I. Making up people. In: Thomas $\mathrm{CH}$, Morton S, David EW, editors. Reconstructing Individualism, Autonomy, Individuality, and the self in Western Thought. California: Stanford, Stanford University Press; 1986.

2. Hacking I. Making up People. London: Review of books, 2006. p. 23-26.

3. Vázquez F, Moreno A. Sexo y razón. Una genealogía de la moral sexual en España. siglos XVI-XX. Madrid: editorial Akal. 1997.

4. Vázquez F, Moreno A. Historia de la prostitución en Andalucía. Fund. José Manuel Lara: 2004.

5. Vázquez F. y Cleminson, R (2007) "Los invisibles". A history of Male Homosexuality in Spain (1850 -1940), Cardiff: University of Wales Press, Iberian and Latin American Studies, 2007. Traducido al castellano en la editorial Comares, Granada, 2012.

6. Foucault M (2006) Seguridad, territorio, población. Trad. Horacio Pons. Buenos Aires: Fondo de Cultura Económica, p. 10. 